\title{
PSYCHOLOGICAL ASPECTS OF IMAGE FORMATION AS AN IMPORTANT INDICATOR OF CS PERFORMANCE IN THE CURRENT CONTEXT OF CORPORATE CULTURE DEVELOPMENT
}

\begin{abstract}
Sergey Storozhuk ${ }^{1}$

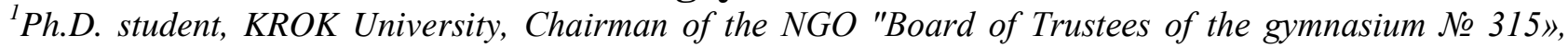
Gymnasium teacher № 315 of the city of Kyiv, Kyiv, Ukraine, e-mail: s.storozhuk01@gmail.com, ORCID: https://orcid.org/0000-0001-9397-6296

Abstract. This article examines the value and grounds of using the concept of image for the implementation of effective activities of public organizations in the current market conditions. Particular attention is paid to the types, principles, as well as psychological criteria of image maintenance technology. Under the conditions of competitive market economy, the image of the company becomes increasingly important. After all, every organization functions in the economic space, where certain moral values, principles and culture have been formed. Therefore, enterprises and managers must build their relations with their employees and partners on the basis of ethics. At this time becomes real need to distinguish themselves from the community of similar, to gain a certain reputation. Entrepreneurs are trying to catch the attention of specific target groups: investors, shareholders, partners, customers and other vital and important groups of society. Therefore, the word "image" is everywhere - it enters into the minds of people, enshrines all spheres of human activity and is everywhere in controlling people's behaviour. The success of the activity and prestige of the organisation depends to some extent on its image. This can be seen as a system of perceptions of the organization and its employees.
\end{abstract}

Keywords: image, company image, stylish image, kerated image, external image, internal image, positive image, negative image, image psychology, image of a public organization.

JEL Classification: D82, D83, I21, I25, M11, M12, M14

Formulas: 0; fig.: 7; tabl.: 0; bibl.: 10

Introduction: It is not difficult to establish that a strong image is a prerequisite for a community organisation to achieve sustainable and long-lasting business success. In the current system of market relations the life of a firm is determined not only by what it does and how it does it, but also by what other people think about it.

That is why creating the face of the public organization has always been one of the most important missions of business leaders and heads of these organizations around the world - the pursuit of prestige in the business world, popularity with customers, and the reputation among partners and customers. clients, credibility in the eyes of the employees.

And what people think about the organization determines in many ways its competitiveness. Whether or not image, as a socio-psychological phenomenon, influences the life of any enterprise (including a public organization).

Literature review. The essence of image was discussed by such prominent scientists as M. Pashkevich, O. Finagin, whose research analyzed the new analysis of innovative methods and modern approaches to image formation of territories as instruments of business activity activation, stimulation of investments and innovations of public administration at the level of the region, as well as the key factors influenced by the image of the region as a motivating factor, A. Surai, the authors have developed a methodology for assessing the level of development of the business environment of the world's countries in a global and regional context, using 
the indices of international analytical organizations, T. Fedorov, who analyzed the main concepts of image and reputation in the sphere of public administration, characterized the main factors that affect the formation of image and reputation of public authorities, practical approaches to image and reputation management in the field of public administration (Fedorov), and Panteleichuk.

She analyzed theoretical and methodological as well as practical aspects of shaping positive image of public authorities, N. Shcherbak, who examined the shaping of positive image of public authorities and local self-government bodies, new approaches and instruments for creating positive image of the state power bodies and local self-government bodies as one of the priority directions of implementation of the new corporate culture and modernization of public administration in Ukraine and some others have been determined.

But today, when structural reforms are taking place in our state, the above mentioned issue is gaining relevance for public administration. This prompted the choice of the topic of the article.

Aims. The aim of the article is to investigate the image as an important indicator of public organisation performance in the current conditions of corporate culture development, as well as to investigate the psychology of CS image formation.

Methods. A method is a way of grasping the essence of a subject, recognising it through a system of cognitive and transformative tools and principles. During the work on this topic, we gave preference to such methods: general scientific research methods - empirical (experiment, observation, description) and theoretical (analysis, synthesis, abstraction, generalization, induction, deduction, explanation, classification, etc.), as well as systemic, functional, concrete sociological.

Results. In the current context of scientific development, significant attention is paid to the concept of "image".

The concept of "image" is given considerable attention in the current conditions of scientific development. In the period of the postindustrial development of society, image is closely connected with the problem of the quality of human life, when the quality of products that affect people is determined not so much by their technological characteristics as by their image equivalents, such as reputation of the manufacturer, good advertising, etc.

The field of public administration is no exception. For example, the employee begins to work on creating his or her own positive image of a professional.

A positive image is the main criterion for the success and efficient development of a community-based organization (CS). Science tries to answer the questions: what is the image, which elements it is composed of, when we can talk about the CS professional image, what is the psychological basis of the image (i.e., what it is composed of).

Taking into account the multiple structural disruptions in the domestic social and economic segment and the Ukrainian state's desire to achieve European standards and receive public services of new quality, the need for a positive image in CS becomes particularly urgent. 
Regardless of the type of organisation Regardless of the type of public relations organization, image management is defined as the basis of the fundamentals of PR, because image is the most effective way of of mass awareness.

Reflecting the needs of the masses, it is easily captured and preserved in people's people's memory. The image is composed of the riches, which, on the one hand on the one hand, are of interest to the the communicator, and on the other, are meaningful to the the audience.

The main characteristic of an image is its implicit orientation, because it the image is the main characteristic of the image is its orientation because it must match both the capabilities of the wearer and the needs of the audience. the needs of the audience.

Now the concept of image has expanded to the size of the corporate world and the total communication field around it.

Image is one of the forms of manifestation of corporate culture. The concept of "image" was proposed by the American economist K. Balding in 1961 [7]. The image is based on: 1) the style of internal and external business and international relations of the staff; 2) official attributes: the name of the organization, logo, trademark; 3) reliability; 4) orderliness; 5) persistence; 6) culture; 7) social responsibility.

Today, image is one of the most important characteristics of the organization, a factor of trust in its products, and consequently, it is a condition for its prosperity.

The mission of the objective of image creation is not to make the organization popular, but to ensure a positive image for the organization and its products to ensure a positive image of the organization. The image is dynamic and can change under the influence of circumstances and new information. It is created with purposeful effort and depends on each employee. There are many definitions of the concept of "image", the following are some of them.

According to L E Orban'Lembrik, the image (from the English word image image) is attitude which the organization and its employees create towards people and which is formed in their conscience in the form of certain emotionally indoctrinated stereotypical perceptions (thoughts, judgments about them) [7].

A.K. Semyonov believes that the image is inherently projected in the interests of the firm, based on peculiarities of activity, intrinsic laws, characteristics, merits, qualities and characteristics of an image that is purposefully included into the knowledge (awareness) of the target audience, meets its expectations and serves as a difference between the company and its peers $[5,87]$.

V. Sizonenko notes that image is a positive image of any company that forms a stable competitive advantage through the creation of a general image, reputation, public opinion, customers and partners about the company's prestige, its products and services, after-sales service [2, 139-143].

According to Markos Szijepanis, the head of a number of large Greek and Cypriot companies, the image of any company is made up of a number of things that are interconnected with the organization of production [3, 45-46].

The main lines are: responsibility, speed, efficiency. The image is created by the combined efforts of all employees without exception. First of all, it is necessary to 
create an image within the company, among employees, and then - within the country. Building a good image is a lengthy and painstaking process.

First and foremost, you must remember that image is a psycho-social phenomenon. It does not exist only at the level of the individual, which means that the object must be recognizable to a certain group of people (customers, clients, etc.), but also must be meaningful to members of the group, to attract the

Attract interest and attention; secondly, it is dynamic in that its attributes can be modified or seen as a function of changes in the wearer or the thirdly, it is active in nature: it can have an impact on the intelligence, emotions, performance and actions of individuals as well as entire population groups [1]. Therefore, the image of CS is the sum total of the public perception of the company or the firm by many people. The image of CS is formed by personal contacts between people and CS; on the basis of rumours circulating in The CS and the public, and from mass-media reports.

Speaking about image characteristics, we can't help mentioning the following: 1. adequacy, credibility - the image created must correspond to what is true.

2. the image must be a complex creation. It is not just a trademark, design or picture, which is easy to is not just a trademark, a design or a picture that can be easily remembered. It is an authentic biography or history of the CS.

So the consumer focuses not only or only on the text and illustrations but they are indirectly interested in the qualities that make up the identity of the company.

The image of the firm is a kind of "medal", one side of which is the internal image of the company rooted in the conscience of the members of the firm, and the other side is its external image recognized by partners, competitors, financial and credit institutions, tax authorities, etc. It can be formed spontaneously and purposefully.

However, very often the managers "do not have time" to follow the emerging image of their company. After all, all the efforts, mainly given to the formation of productive capacity of the enterprise. In these cases, a stylish image is created, which has, both positive and negative reactions, of course, so that one and the same CS may be perceived as opposed to the other.

We believe that it is often correct to start the image-building work at the same time as the CS is being established.

A good image is the result of a complex, well-respected activity, aimed at creating, supporting and enhancing positive public opinion about the company and its products (services) $[8,17]$.

Thus, the image work is complicated and involves a lot of processes and it is very necessary, especially if the company wants to establish itself on the market and have good prospects for further development [6, 228-229].

It is important for the success of the company not only the external but also internal image.

From a psychological point of view, the perception of the organization is one of the structural components of conscience, which has specific features without which it is impossible to correctly understand the perceptions and purposefully influence 
them. On the other hand, image is the impression a person or organisation has on individuals or groups.

This means that knowledge of the process of perception, interpretation of any facts, information about the individual, the organization of a particular group of people is one of the most important aspects of image management.

On the basis of the image, the perception of the manufacturer and its products is predicted. The practice proves that the hidden costs and efforts to manufacture environmentally friendly, ecologically odourless products are a prerequisite for their high marketability. The logical conclusion is the economic prosperity of the organisation, the manufacturer or if for some reason and not so - the attempt to repeat their reputation, which also attracts respect.

It is about style, that is, the most characteristic thing in its image - the external appearance, the internal image, which is the basis for the recognition of the organization for the whole manner. The image of the organisation can be both positive and negative. The basis of positive image is trust in the organization, appropriate stereotyping of its perception [7].

Ethical behavior of an enterprise is a powerful tool for shaping a positive image [5, 457]. Every businessman and manager must constantly be concerned that all aspects of the firm's life are maintained of the company's life work for the creation of a positive image $[2,176]$. Negative image is manifested in distrust of the organization and its reputation. As a rule, a positive image of the organization saves its resources, while a negative one considerably increases costs.

The positive image of the organization depends on certain factors: management efficiency; corporate culture; environmental safety; quality, financial capacity and competitiveness of goods (services); and replication of the organization's name through mass media.

Most organisations pay special attention to ethical norms because the company's image and reputation depend on them to a significant extent. Often they are faced with a dilemma: to act ethically, but do not lose potential profits or reach the set goals by any means, that is, work on the principles of the XV century philosopher. Niccolò Machiavelli, "the goal justifies the means" [4, 67-68].

Experience shows that when the firm plans its operations in a short-term period, without having in mind future development, the firm prefers the second option.

However, if the company wants to achieve a stable position on the market, establish mutually beneficial and fair relations with its partners, ensure a successful and profitable business and profitable business in the long term, all actions and activities of its employees must be based on ethical norms and business ethics.

The strategy of ethical behaviour often induces enterprises to refrain from very trade-favourable propositions, which forms and strengthens their reputation in business circles. This confirms the feasibility and viability of investments in ethics.

Entrepreneurs are often not keen on long term prospects, which require hard work and a reputation for being free of debt, so they may be tempted by unethical options (negotiating with unhappy business partners, etc.). However, one should always bear in mind that unethical and illegal actions may result in someone being 
hurt and someone being held liable, as a result of which the company will receive a loss exceeding the profit gained by illegal means [8, 74-81].

Private interest is a great motive and there is no stronger one. But the way to achieve the seller's self-interest in market conditions is only through the implementation of the buyer's interest $[6,30]$. The image creation technology takes into account the following components:

- the approach to the distinctions that distinguish a certain object among others;

- identification of characteristic features;

- writing down a person in a symbolic concept of a leader, selecting his or her

characteristics corresponding to this idealization;

- writing down the person in the model of the already realised leader;

- inclusion of the person into the model of the author's behaviour, i.e. into the context of the symbolically imposed subject;

- active use of associated symbols to create visual active use of associated symbols to create visual characteristics;

- active management of mass communication means;

- fight against autonomous flows of communication (ghosts, etc.);

- symbolization of autonomous spheres (clothes, hairdo, etc.).

The impact of the organization's image on consumers of services or goods can be made by different models and formulas. One of them is a scheme of behavioral management by means of a demonstration image. Formation, maintenance and growth of the image requires a pronounced, grounded activity of the entire enterprise team.

If we compare the psychological basis for image formation CSO and the whole country, we find that the psychological mechanism of the image of the country is a socio-cultural, ethnopsychological stereotype, which forms the basis not only about individual people, but also about the companies of these countries, their products and services. For the prosperity of the organization requires a constant expansion of markets for products (services), increasing the number of customers, etc. For this purpose, psychological mechanisms of influence are used such as: imposition, influence, reappraisal, "contamination" [8, 546-549].

Communication and interaction with people in the sales market is realized with the help of offered products and services.

The quality of goods (services) is a mirror of the CS. The quality of the product is a sign that determines our attitude towards the company [7]. After all, faced with substandard product, everyone experiences negative attitude not only and not only to their own product, but to the company, which produces and sells this product. And on the other hand, coming across a quality product, the consumer begins to look for all the other varieties of products, which are produced by a particular company. This is why there is a global market struggle for the quality of the products in the world market is the primary focus of the competition. This is because it is the psychology of the consumers.

The psychological mechanism of the image of the country is a social stereotype. This image level is used to strengthen the position of the goods (services) on the 
market: "Good American Cigarettes", "Genuine German Quality", "Genuine French wine".

Discussion. For most Western businessmen, the Ukrainian market is an area of high risk due to the unstable state policy and legislation. Also, the company's longstanding positive public image may become a real asset in times of crisis. Hess, Rogowski and Dunphy provide a dramatic example where a good reputation has shaken McDonald's during the 1992 Los Angeles riots. The company's dedication to building good community relations through the Ronald McDonald House and its participation in the creation of new workplaces provided the company such strong credibility that rioters in turn did not scratch McDonald's outlets. The vandals, causing great damage to local businesses, destroyed $60 \mathrm{McDonald}$ 's restaurants.

The image problem is one of the central issues in psychology. The study began in the works of I. M. Siechenov, who viewed perception as "tricks of the real", that is, its patterns that are created on the basis of the reflexive activity of the brain.

In reflecting reality, they perform regulation of behavior and provide for its adequacy their appropriateness to the environment.

The category of image is included in cognitive processes. Numerous scientific and theoretical investigations of domestic psychology are devoted to revealing the essence of these processes on the basis of their In their behavioral capabilities (B.G. Ananiev, S.B. Kravkov, O. M. Leontiev, S. L. Rubinstein, B. M. Teplov, and others).

The image has often been the subject of study by various branches of science, which is connected with the presence of a specific person. This is due to the presence of a personal orientation in all spheres of social activity. In this way the image from a philosophical point of view is grounded in moral principles and is studied in connection with them.

In the sociological view, an important role is played by a recurring and recognised image, the building blocks for which are the of society, the stereotypical framework to which it is "adapted". From the political point of view, the image is often considered to be the political image of the person-politician, together with his external and internal characteristics as well as his electoral campaign, biography, desires and so on.

Psychology sees image as a totality of valuable and personal characteristics (the image is easy to remember, to be clearly expressed, based on a low level of personal characteristics, which are attractive to the individual).

On the basis of the study of "image" by various sciences we can state that the formation of image is a topical problem of our time. From the moment of the role of image in the course of historical, socio-economic, and political processes, there has been a desire to control its in the course of the historical, socio-economic and political processes, there is a desire to control the process of its creation and the image starts to be used in CS to achieve a certain goal, acting as a transmitter of socially relevant information. 
Conclusions. The image, then, is the impression that a company makes on the public and that is recorded in their minds in the form of more or less inflamed emotionally charged thoughts or judgements about it.

These perceptions always appear to be generalised, i.e. by referring even to some, perhaps minor or partial details, people interpret them and they form an overall image of the company. This is why it is safe to say: there is and can be no difference in the image of the CS. Ethical or amoral business practices are an expression of the system of values that has developed in society, a particular social group or organization. Therefore, ethical norms of behaviour it is necessary to implement them on the basis of cultural level education and teaching ethics to every member of the team.

The main tasks to maintain the image of the company, first and foremost, should include:

- Compliance with moral integrity and universally recognized standards of morality.

- Fostering a supportive public attitude towards the enterprise's operations to ensure its smooth operation and broadening its sphere of influence.

- Improvement of interoperability between the enterprise and all stakeholders.

- Creation of a "public image" of the enterprise and preservation of its reputation.

- Increasing the impact of the company through propaganda, advertising, etc.

\section{References:}

1. Atamanska, K. I. (2012). Teoretychni aspekty poniattia imidzhu v naukovykh doslidzhenniakh [Theoretical aspects concept of image of scientific research]. Problemy suchasnoi pedahohichnoi osvity. Pedahohika i psykholohiia. Is. 37 (2). P. 28-32 [in Ukrainian]. Varna, N. V. (2007). Imidzhelohiia [Imageology]. Un-t «Ukraina». Kyiv [in Ukrainian].

2. Kovbasiuk, Iu. V. (Ed.) (2011). Entsyklopediia derzhavnoho upravlinnia [Encyclopedia of Public Administration]. Kyiv [in Ukrainian].

3. Zinchenko, O. M. (2006). Do pytannia profesionalizmu $\mathrm{v}$ derzhavnii sluzhbi [On the issue of professionalism in the civil service]. Visn. derzh. sluzhby Ukrainy. Is. 1. P. 17-20 [in Ukrainian].

4. Krynychna, I. P. (2013). Suchasni pidkhody do formuvannia imidzhu derzhavnoho sluzhbovtsia [Modern approaches to the image of a civil servant]. Publichne administruvannia: teoriia ta praktyka. Is. 1. Retrieved from: http://nbuv.gov.ua/UJRN/Patp_2013_1_22 Larina, N. (2013). Imidzh yak komunikatyvna osnova pozytsionuvannia vlady [Image as a communicative basis for positioning power]. Visnyk derzhavnoi sluzhby Ukrainy. Is. 2. P. 20-23 [in Ukrainian].

5. Pantelejchuk, I. V. (2011). Formuvannia pozytyvnoho imidzhu orhaniv derzhavnoi vlady: teoriia, metodolohiia, praktyka [Formation of a positive image of public authorities: theory, methodology, practice]. Kyiv [in Ukrainian].

6. Pachkevych, M. S., Finahina O. V. (2017). Formuvannia pozytyvnoho imidzhu terytorii yak bazys rozvytku dilovoho seredovyshcha rehioniv Ukrainy [Formation of a positive image of territories as a basis for the development of the business environment of the regions of Ukraine]. Visnyk Berdians'koho universytetu menedzhmentu i biznesu. Is. 4 (40). P. 74-78 [in Ukrainian].

7. The Verkhovna Rada of Ukraine (2016). The Law of Ukraine "About the civil service". Retrieved from: https://zakon. rada.gov.ua/laws/show/889-19 Serohin, S. M. (2004). Derzhavnyi sluzhbovets u vzaiemovidnosynakh vlady i suspilstva [Public servant in Relations Between the authority and the Society] (Doctor's thesis). Kyiv [in Ukrainian].

8. Serohin, S. M. (Ed.), Lola, V. V., Khozhylo, I. I. et al. (2009). Formuvannia pozytyvnoho imidzhu orhaniv vlady cherez pidvyshchennia yakosti nadannia administratyvnykh ta sotsialnykh posluh [Formation of a positive image of the authorities through improving the quality of administrative and social services]. Kyiv [in Ukrainian]. 